\title{
New Faunal Conditions in the Canal Zone*
}

\author{
Notes of an Expedition to Investigate the Results of the Physical Changes in this Region \\ By H. E. Anthony
}

DURING the months of February and March of last year it was the good fortune of the author to accom pany, as an American Museum representative, $\mathbf{M r}$. George Shiras, 3rd, on a trip to the Canal Zone. Mr. Shiras desired to obtain photographs by flashlight of the animal life of that region, a method of which he is one of the foremost exponents to-day and which has regions. It was through his generosity that the Museum was able to send a collector to Panama with him.

It was expected that faunal conditions in the Canal Zone would be undergoing abrupt changes because of the damming of Gatún Lake and the consequent extensive high water. From a basin with no lake worthy the name, with standing water conflned largely to marshy areas except during the height of the rainy season, the Gatún region has been transformed by the huge dam at the locks into a lake of one hundred and sixty-four square miles in extent and a depth of seventy to eighty feet in many places. This flooding of ground formerly high and dry, it was anticipated, would drive many animals to seek new homes or might even threaten some of the more restricted, lowland-living animals with extermination. Incidentally many of the islands and ridge crests left above water might have a concentrated fauna driven there from the adjacent flooded localities. Other phases of the question dealing witb the newly created lake were the wiping out of the lowland forests by submergence, the rise of new aquatic flora, such as the water hyacinth, and the probable inhabitation of the lake by water birds. Such were some of the items in the purpose of the expedition and we were equipped to take advantage of these new conditions if the foregoing assumptions proved correct.

As Gatún Lake was the center of investigation, it was planned to work from a house boat as a base camp, with a launch and small boats for side trips. Accordingly a boathouse was made over by a few alterations, but only after considerable time had been spent in trying to secure something available for the purpose. The house boat was so low in the water that she could be towed only in a calm sea, a condition of the lake only rarely met with, and at best the launch could make but slow time pulling her. Late afternoon of March 6th saw us leaving Gatún with the house boat and by 3 o'clock the next morning we were tied up at the head of a waterway or trocha that branched off from the Rio Trinidad. This was our main camp and we hoped to be able to work the undisturbed jungle from here. Unfortunately, a plantation nearby, a young fruit district only recently made accessible by high water, chose this time to burn over some clearings, and we found that the smoke materially interfered with our success. Cameras with terially interfered with our success. Cameras with
llashlights and bait were set out in promising spots, lines of traps for mammals were run daily, while the jungle was hunted in hopes of shooting specimens.

It was at this spot that we made the acquaintance of the largest of the Panamanian monkeys, the "black howlers." Frequently their queer booming, roaring howl echoed through the jungle, a call that carries for long distances. They howl oftenest just before or during a rainstorm and the natives thus look upon. them is weather prophets. Upon one occasion I stood almost under some trees through which a troop was passing, while the flrst big preliminary drops of a sudden shower pattered upon the leaves about me. The volume of sound that issued from the black shaggy throats was so great and so suggestive of a large animal, a lion for example, that I found it hard to reconcile myself to the actual facts. I felt a pang of regret at silencing one of the "howlers," but as a specimen was needed I shot one of the foremost and heard him crash through the limbs to the ground. Pangs of a more effective sort were experienced when my native boy and I attempted to retrieve the monkey, for he had fallen underneath a bees' nest the size of a bushel basket and we found the nest too late to avoid it.

Other interesting mammals encountered here were the pretty squirrel-like marmoset, the short-haired anteater

"The expedition worked under authority from the Cana Commission. It is of note that Colonel Goethals, as the first civil governor of the Canal Zonc, continues adherence to th policy he maintained during the engineering work in the
region. namoly. that the Isthmus shall he a game preserve.

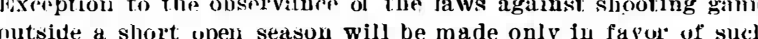
creasional zoological expent

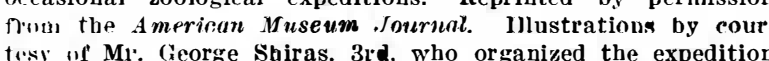
and made the flashlight photographs; and also of the author, who photographed the general scenes. and several species of opossum, while we were contindiversity of the bird songs and callnotes. The noisy parrots that shouted in the morning until the jungl rang with their tumult, the grotesque toucans which a times vied with the parrots, the calling of the parrakeets, and the peculiar chorus-like calls of the chachalaca, or "wild turkey," produced an impression that must ever be associated with jungle memories. At night mysterious noises were heard from unknown sources, and one weird laughing call in particular caused conjecture to run rife, there being as many opinions as there were listeners

Besides the work done on the Rio Trinidad, severa long trips were made by launch far up the river as the launch could ascend and two others up the Rio Chilibrillo to some limestone caves for bats. On these trips it wa found that the rising waters had ascended far up the river valleys, which in this part of the region have ver little fall, making them navigable to launches where formerly it would have been impossible to take a cayuc or native dugout. Some of these flooded rivers-rivers by courtesy, for in the States these streams would be called creeks-with their banks densely lined by jungle vegetation which met overhead and dropped long vine and streamers into the waters, were very beautiful. Everywhere we found the forest inundated. In regions early flooded, where the trees were submerge for the greater part of their height, all the trees were dead and leafless with an occasional great clump of orchids, the only green left. Many square miles of the surface of Gatín Lake are thickly studded with dead tree-tops of what was at one time splendid tropica forest. In regions of later high water many of the trees were still green and blossoming; especially was this so along the shores where but the lower part of the tree trunks were under water. It is not improbable that some of the more resistant trees may live to a ripe old age with their roots some feet below the surface of Gatún Lake, for some species were found flourishing among their long since dead companions. No new aquatic growth, arisen to take advantage of the altere conditions, was noted, but the conditions had probably not been in operation long enough to bring about such a growth. The dead trees are constantly falling and the far-reaching crash of their descent is one of the common sounde of the lake.

Gatún Lake will undoubtedly produce new economic conditions among the natives of the adjacent district. These natives formerly had no other waterways but the few rivers that traversed the interior basin, and were available for navigation only to a limited number of villages. Such rivers were the Chagres, Trinidad, and Gatún. Now the far-extending lake shores provide such an accessible waterway that the natives are learning to
navigate on lake waters, and every morning their cayucas may be seen lined up at the native market along the lock-front at Gatín. Being primarily rive boatmen, however, they are yet somewhat distrustful of boatmen, however, they are yet somewhat distrustful of when the winds die down. During the dry season, from January to April, the winds blow across the lake toward a northern quarter of the compass, and just the reverse holds true for the rest of the year. This wind at times becomes strong enough to threaten small boats seriously, and at practically all times of the day would be a strong check on the progress of the native dugout. that was facing it. We found it necessary to move the house boat always at night and in the early morning hours because of this wind, and this proved a serious ohstacle to working many localities, because it was out of the question to run at night without a moon, and when we most wished to move we had a late rising moon. After driving the launch full-tilt over a floating tree and into partially submerged bush and tree tops,
trying to steer by lantern light, we conflned our future movements to moonlit hours.

Whenever one left the waters of Gatin Lake the dense, unaltered jungle was at once encountered and no matter how much its beauty was to be admired from the boat, its impenetrability was no less to be deplored. It was useless to attempt to leave the trail without recourse to the machete, the long brush knife of Iatin Americil. and many were the varieties of briars and thores to be alvided. Once into the thick growth of the jungle, the hunter found it necessary to stand minute in one spot in orfer to look into all the arboreal nooks and crannies, so many were the possibilities, so many the great orchid-covered limbs and wide branching trees, and so loath to move the denizens of the jungle. The orchids and epiphytic air plants were very abundant down the limb or even the entire tree that harbored them, and not infrequently I witnessed the downfall of some tree overburdened in this manner; once indeed, warned by a premonitory cracking, I was forced to move with considerable speed to escape a flying limb.

Mosquitoes, the former bane of early Canal days, were found but sparingly. Even outside the district of government patrol we were bothered but little by them, although we were told that later, during the rainy season, they were much worse. A few spots were encountered where mosquitoes were bothersome, thus arguing a local distribution. The ticlss and red bugs, however, made up in diligence for any slights we might feel we had suffered from not being met by mosquitoes. The jungle everywhere seemed to harbor these pests and they did all they could to make life miserable for us. Ants also were found in abundance and it was fortunate indeed that our camp was a floating one and thus cut off from inroads of these nuisances. One species of ant in particular will be long remembered by two members of the party, for it stung with a venomous vigor never equalled by any bee and made the victim imagine he had been struck by a snake at least.

Concentration of animal life had taken place at the rising of Gatún Lake, and most of the islands formed had many inhabitants at flrst. The Gatún Hunt Club, however, soon reduced the population of these islands by hunting them with hounds, and as the quarry in most instances could not leave the island, the result was clean sweep of all the larger species. We were too ate, consequently, to flnd abundant game on any of the islands near Gatín. I accompanied this hunt club on one occasion, securing two peccaries.

The most efficient method of hunting the Panamanian jungle was by means of a headlight at night. The rays of the light, worn on the hunter's head, are reflected by the eves of the animal, which shine like two orbs of fire--red, green, or bluish, depending on the animal "shone." The.hunted animal will see nothing but the approaching light and falls an easy victim to the rifle or shotgun. On account of the danger to domestic stock and to people by promiscuous shooting at night, this method has been prohibited on the Zone, but beyond Zone limits it is to-day the favorite mode.

The trip resulted in a good series of flash light photorraphs of opossums and some of the smaller mammals. The apparatus for "flashing" the animals was set out by some runway or water-course where animals were apt to pass, and consisted of a mechanism to fire a magnesium flash and at the same time trip the shutter of the camera, which was fastened in a manner to command the trail. A thread attached to a bait and stretched out before the camera flred the flash when the animal pulled it.

Series of the rodents and the smaller mammals were secured for the Museum collections and for the most part are of species not hitherto represented. The time was too limited to secure many of the larger mammals which are found in the Zone.

\section{Electric Power for Agriculture}

THE idea of applying electric power to agricultural perations is attracting attention, especially in view of the great hydro-electric plants that are being developed n districts remote from present manufacturing activiies, where the power must be transmitted great distances. If some of this power could be utilized locally it would be a good thing for both the producer of electricity and the user, as it would enable a higher continuous steady load to be carried on the generators, and this in turn would enable the power to be sold at a ower rate, as more power would be produced without increasing the overhead expenses. One obvious application of electricity in some districts would be for running irrigating pumps, and this could be done economically if enough power was taken to pay for the installation of the lines. There is considerable machinery on every farm that requires power to operate and Wich conld ntilize electric power to alvantage if the ost was right, and the introduction of power for pumning plants would lead the way to making this kind of power for farm machinery generally. If an irrigating Jlant can be so arranged that it can serve several different tracts of land a steady load is furnished that can be supplied cheaply by the power station. 